DOI https://doi.org/10.30525/978-9934-26-184-8-2

\title{
ВПЛИВ МІНЕРАЛЬНИХ ДОБРИВ НА ВРОЖАЙНІСТЬ ПШЕНИЦІ М'ЯКОЇ ОЗИМОЇ В ПІВНІЧНОМУ СТЕПУ УКРАЇНИ
}

\section{Гасанова I. I.}

кандидат сільськогосподарських наук, старший науковий

співробітник,

провідний науковий співробітник лабораторії агробіологічних

ресурсів озимих зернових культур

Державна установа Інститут зернових культур

Національної академії аграрних наук України

\section{Ноздріна Н. Л.}

кандидат сільськогосподарських наук, стариий викладач кафедри рослинництва

Дніпровський державний аграрно-економічний університет

\section{Єрашова М. В.}

кандидат сільськогосподарських наук,

молодший науковий співробітник лабораторії агробіологічних ресурсів

озимих зернових культур

Державна установа Інститут зернових культур

Національної академії аграрних наук Украӥни

м. Дніпро, Украӥна

Пшениця м'яка озима (Triticum aestivum L.) - найцінніша продовольча культура не лише в Україні, але і в світовому масштабі. Зростання валових зборів зерна, в першу чергу, залежить від урожайності, на формування якої впливає ряд факторів, одними з основних серед них є прийоми агротехніки. За дослідженнями провідних вітчизняних та іноземних науковців пшениця озима дуже чутлива до удобрення посівів. Встановлено, що науково-обгрунтована система внесення добрив сприяє 
суттєвому підвищенню врожайності цієї культури та поліпшенню якості iї зерна $[1$, с. $50 ; 2$, с. 59; 3, с. 282-284; 4, с. 239-240; 5, с. 503-504]. Але із впровадженням нових сортів пшениці озимої у виробництво на тлі кліматичних змін, ряд питань підлягає додатковому вивченню. До того ж, останніми роками в степовій зоні України все більше сіють пшеницю після небажаних 3 агрономічної точки зору попередників: зернові колосові, ріпак, соняшник та ін. Стабілізація виробництва зерна після таких попередників - важливе завдання сьогодення.

В умовах дослідного господарства «Дніпро» ДУ Інститут зернових культур НААН (Дніпропетровська область, Північний Степ) у різні роки досліджували вплив удобрення посівів на врожайність пшениці м'якої озимої після попередника ячмінь ярий. Під передпосівну культивацію вносили фонове добриво $\mathrm{N}_{60} \mathrm{P}_{60} \mathrm{~K}_{30}$, до сівби насіння протруювали фунгіцидом Вітавакс 200 ФФ нормою витрати 2,5 л/т насіння. Ширина міжрядь 15 см, глибина загортання насіння - 5-6 см, строк сівби оптимальний для зони - 20 вересня. Збирання врожаю проводили поділяночно комбайном «Sampo-500». Площа облікової ділянки становила 30-35 м².

У 2011-2014 рр. висівали сорти пшениці озимої Литанівка, Заможність, Антонівка, Сонечко та Розкішна; в 2015-2018 pp. Коханка, Місія одеська та Пилипівка. Серед вище перелічених сортів Литанівка - безостий; високо інтенсивні сорти - Литанівка, Заможність; універсальні - Антонівка, Розкішна, Місія одеська, Коханка; напівінтенсивного типу - Сонечко, Пилипівка. Варіанти удобрення у досліді, який проводили у 2011-2014 рр., були такими: без підживлення (контроль); $\mathrm{N}_{30}$ локально наприкінці фази кущіння рослин, аміачна селітра; $\mathrm{N}_{30}$ наприкінці фази кущіння, КАС-32; $\mathrm{N}_{60}$ локально, аміачна селітра; аміачна селітра $\mathrm{N}_{30}$ ранньою весною по мерзлоталому грунту (МТГ) $+\mathrm{N}_{30}$ локально; $\mathrm{N}_{30}$ локально, аміачна селітра $+\mathrm{N}_{30}$ у фазі колосіння, карбамід. Аміачну селітру вносили врозкид поверхневим способом та за допомогою сівалки локально, карбамід і КАС-32 шляхом обприскування вегетуючих рослин ранцевим обприскувачем, регулюючи дисперсність розпилювання розчину залежно від форми добрива. У досліді, що проводили у 2015-2018 рр., 
для підживлень використовували виключно азотне добриво аміачна селітра і варіанти були наступними: без підживлення (контроль); $\mathrm{N}_{30}$ ранньою весною по МТГ; $\mathrm{N}_{60}$ по МТГ; $\mathrm{N}_{30}$ локально наприкінці фази кущіння рослин; $\mathrm{N}_{30}$ по МТГ $+\mathrm{N}_{30}$ локально; $\mathrm{N}_{60}$ по МТГ + $\mathrm{N}_{30}$ локально.

На ріст, розвиток, формування продуктивності пшениці озимої безпосередній вплив мають погодні умови у період вегетації рослин. Серед років досліджень дуже несприятливі умови склалися у вегетаційний період 2011-2012 рр. Особливо це стосується посівів після непарових попередників, де, як правило, акумулюються менші запаси продуктивної вологи в грунті, порівняно $з$ паровими. Відмічали значний недобір опадів в передпосівний, посівний періоди і взагалі упродовж осінньої вегетації. Перед зимівлею посіви після ячменю ярого у дослідах були зріджені і неоднорідні, висота рослин становила в залежності від сортів від 17,8 до 21,2 см, кількість пагонів у середньому по сортах відповідала 1,6 шт. на одну рослину, а вузлових коренів 1,8 шт. У грудні та в першій декаді січня 2012 р. переважала незвичайно тепла погода (максимальні температури повітря в найтепліші дні досягали $8-14{ }^{\circ} \mathrm{C}$ ). Це погіршувало загартування пшениці озимої і призводило до витрати поживних речовин в рослинах та послаблення їх зимостійкості. 3 середини останньої декади січня і майже до кінця другої декади лютого утримувалась дуже холодна, суха погода. Середньодобові температури повітря в найбільш холодні відрізки часу знаходились у межах $-11--24{ }^{\circ} \mathrm{C}$ та на 6-19 ${ }^{\circ} \mathrm{C}$ були нижчими за норму. Температура повітря в найхолодніші ночі знижувалась до $-25--30{ }^{\circ} \mathrm{C}$, що також негативно впливало на стан посівів пшениці озимої.

Не досить сприятливими виявилися гідротермічні умови i упродовж весняно-літнього періоду вегетації. 324 квітня і до кінця червня 2012 р. встановилася аномально спекотна, з недобором опадів погода, що пришвидшило настання фаз розвитку рослин пшениці та призвело до передчасного вистигання зерна озимих культур, особливо після непарових попередників. Кількість продуктивних стебел цього року у посівах пшениці озимої після ячменю ярого становила залежно від сортів 
166,2-214,7 шт./м², тим часом як у 2013 та 2014 рр. значення цього показника були вдвічі більшими.

Якщо розглядати погодні умови в 2015-2018 pр., то варто відмітити, що в осінній період 2015 р. внаслідок аномально тривалої посухи на фоні підвищених температур повітря сходи після ячменю ярого взагалі у звичайні календарні строки не 3'явилися. Повні сходи після цього попередника були отримані лише у лютневі «вікна», під час потеплінь. I тільки завдяки виключно сприятливим гідротермічним умовам у весняний період вегетації рослини пшениці озимої розкущилися, сформували розвинуту кореневу систему та оптимальну надземну вегетативну масу, що стало запорукою формування досить високого врожаю зерна після ячменю ярого (на кращих варіантах не менше 5 т/га).

Внесення мінеральних добрив, головним чином азотних, $\epsilon$ надзвичайно важливим фактором технології вирощування пшениці озимої після непарових попередників. Отримані експериментальні дані показали, що врожайність зерна у середньому по сортах пшениці озимої після ячменю ярого суттєво змінювалась по роках. Так, у досліді, який проводили у 2012-2014 pp., в 2012 р. була отримана значно нижча урожайність, порівняно з 2013 та 2014 рр. Це пояснюється різними погодними умовами в період вегетації рослин в роки досліджень.

Слід відмітити, що у посушливому 2012 р. посіви пшениці озимої після непарового попередника мали слабкий розвиток $\mathrm{i}$ внесення азотних добрив у весняно-літній період вегетації було неефективним. У контролі, в середньому по сортах, урожайність становила 2,37 т/га, а у варіантах з підживленнями цей показник змінювався від 2,24 до 2,39 т/га. У сприятливі за температурним режимом та вологозабезпеченням 2013 та 2014 рр. урожайність залежно від варіанта досліду становила 4,16-4,70 та 4,73-5,27 т/га відповідно. Найменші показники урожайності в ці роки відмічали на ділянках без азотних підживлень, а найбільші - за локального підживлення посівів дозою азоту 60 кг/га та у варіанті, де поєднували підживлення аміачною селітрою в дозі 30 кг/га по МТГ та локально у кінці фази кущіння рослин. Більш врожайними у роки досліджень були сорти пшениці озимої Розкішна i 
Заможність, найменша врожайність формувалася у сорту Сонечко.

Найвищий приріст врожаю в 2016-2018 рр. забезпечувало внесення азотного добрива дозою 60 кг/га по МТГ врозкид та у два етапи: $\mathrm{N}_{60}$ по МТГ $+\mathrm{N}_{30}$ локально наприкінці фази кущіння рослин. За такого удобрення в роки досліджень відмічали найбільше зростання продуктивного стеблостою, головного елемента структури зернової продуктивності. Урожайність сорту пшениці озимої Коханка за цих варіантів підживлення, у середньому за три роки, становила відповідно 5,31 та 5,46 т/га, сорту Місія одеська $-4,78$ та 5,03 т/га, а сорту Пилипівка $-5,47$ та 5,62 т/га, що було на 0,82 і 1,20 т/га більше, порівняно 3 контролем, у сорту Коханка; на 0,66 і 1,15 т/га - у сорту Місія одеська та на 0,79 i 1,16 т/га - у сорту Пилипівка. За рахунок таких підживлень рівень рентабельності виробництва зерна зростав залежно від сорту 3 100,1-126,4 \% (контрольні варіанти) до 124,8-156,9 \% за кращих варіантів підживлень.

\section{Література:}

1. Жемела Г. П. Добрива, урожай і якість зерна. К.: Урожай, 1991. $136 \mathrm{c}$.

2. Кривенко А. І. Оптимізація норм і термінів підживлення пшениці озимої азотними добривами у Південному Степу України. Вісник аграрної науки Причорномор'я. 2018. Вип. 4. C. 55-61. DOI: 10.31521/2313-092X/2018-4(100)

3. Нетіс I. T. Пшениця озима на півдні України: монографія. Херсон: Олді-плюс, 2011. 460 с.

4. Черенков А. В., Гасанова I. I., Костиря I. В., Остапенко М. А., Білозор І. В. Вплив попередників, мінеральних добрив та способів сівби на урожайність і якість зерна пшениці озимої в південному Степу України. Зернові культури. Дніпро, 2019. Т. 2, № 2. C. 237-244. DOI:10.31867/2523-4544/0031

5. Litke L., Gaile Z. Effect of nitrogen fertilization on winter wheat yield and yield quality. Agronomy Research. 2018. 16 (2). P. 500-509. DOI:10.15159/AR.18.064 